\title{
PEMBELAJARAN EVALUASI ASUHAN KEPERAWATAN SECARA UMUM
}

\author{
Erta Iman Jelita Harefa/181101138 \\ ertahrf08@gmail.com
}

\begin{abstract}
Abstrak
Latar belakang: Tahap evaluasi merupakan pengawasan manajerial untuk mendapat hasil yang sesungguhnya dibandingkan dengan hasil yang diharapkan. Oleh karena itu evaluasi akan terlaksana setelah melakukan pengkajian, diagnosis, perencanaan, dan pelaksanaan. Dalam tahapan ini, sebagai perawat profesional harus berfikir kritis dari setiap tahap proses keperawatan karena hal tersebut untuk mencapai keberhasilan perawatan.

Tujuan: Penulisan ini bertujuan untuk mengetahui dan memberi informasi tentang pembelajaran evaluasi asuhan keperawatan secara umum.

Metode: Penulisan ini menggunakan metode literature review dengan pendekatan jurnal atau artikel, buku dan $e$-book yang relevan dan akurat serta berfokus pembelajaran evaluasi asuhan keperawatan secara umum. Adapun jurnal atau artikel dan $e$-book yang digunakan pada literature review adalah jurnal atau artikel dan e-book yang didapatkan dengan menggunakan Google Scholar, Portal Garuda, dan Jurnal Keperawatan Indonesia.

Hasil: Berdasarkan hasil pencarian literatur didapatkan hasil evaluasi yang terkait dengan pencapaian tujuan keperawatan sebagai berikut: 1) Tujuan tercapai jika pasien/klien menunjukkan perubahan sesuai dengan standar yang telah ditentukan, 2) Tujuan tercapai sebagian atau pasien/klien masih dalam proses pencapaian tujuan jiak pasien/klien menunjukkan perubahan pada sebagian kriteria yang telah ditetapkan, 3) Tujuan tidak tercapai jika pasien/klien hanya menunjukkan sedikit perubahan dan tidak ada kemajuan sama sekali serta dapat timbul masalah baru.

Pembahasan: Menurut Wilkinson (2007), secara umum evalusi diartikan sebagai proses yang disengaja dan sistematis dimana penilaian dibuat mengenai kualitas, nilai atau kelayakan dengan membandingkan pada kriteria yang diidentifikasi atau standar sebelumnya. Tahapan evaluasi keperawatan dilakukan secara periodik, sistematis, dan terencana.

Penutup: Pada evaluasi asuhan keperawatan secara umum diketahui bahwa hal ini menentukan perkembangan kondisi dari pasien/klien. Dalam evaluasi asuhan keperawatan ini adalah salah satu tahapan yang sangat penting dan berpengaruh pada hasil dari proses keperawatan.
\end{abstract}

Kata kunci: pembelajaran, evaluasi, asuhan keperawatan 


\section{LATAR BELAKANG}

Proses keperawatan memiliki beberapa tahapan yang salah satunya adalah tahap evaluasi. Dalam tahapan ini, sebagai perawat profesional harus berfikir kritis dari setiap tahap proses keperawatan karena hal tersebut untuk keberhasilan perawatan terutama dalam tahap evaluasi. Tahapan evaluasi merupakan tahapan akhir dari proses keperawatan.

Meskipun tahap evaluasi ini diletakkan pada akhir proses keperawatan tetapi tahap ini menjadi bagian integral pada setiap tahap proses keperawatan.

Tahap evaluasi merupakan pengawasan manajerial untuk mendapat hasil yang sesungguhnya dibandingkan dengan hasil yang diharapkan. Oleh karena itu evaluasi akan terlaksana setelah melakukan pengkajian, diagnosis, perencanaan, dan pelaksanaan. Tahap evaluasi adalah suatu usaha untuk mengukur dan memberi nilai secara objektif terhadap penilaian hasil-hasil yang telah direncanakan sebelumnya.

Tahap evaluasi adalah suatu penilaian hasil dan proses yang menentukan keberhasilan yang dicapai dan menentukan kesalahan dari setiap tahapan proses keperawatan. Tahapan evaluasi ini akan tercapai dan terlaksana secara optimal yang dapat dilihat dan diketahui dari pemberian asuhan keperawatan pada pasien/klien. Dalam pemberian asuhan keperawatan terdapat metode yang harus dilaksanakan secara terorganisir dan sistematis serta berfokus pada respon yang unik dari individu terhadap masalah kesehatan aktual maupun potensial.

Asuhan keperawatan merupakan proses atau rangkaian kegiatan praktik keperawatan langsung pada pasien/klien di berbagai tatanan pelayanan kesehatan yang pelaksanaanya berdasarkan kaidah profesi keperawatan (Ali, 2009).

\section{TUJUAN}

Tujuan penulisan ini adalah untuk mengetahui dan memberi informasi tentang pembelajaran evaluasi asuhan keperawatan secara umum.

\section{METODE}

Penulisan ini menggunakan metode literature review dengan pendekatan jurnal atau artikel, buku dan e-book yang relevan dan akurat serta berfokus pada pembelajaran evaluasi asuhan keperawatan secara umum. Adapun jurnal atau artikel dan e-book yang digunakan pada literature review adalah jurnal atau artikel dan e-book yang didapatkan dengan menggunakan 
Google Scholar, Portal Garuda, dan Jurnal Keperawatan Indonesia.

\section{HASIL}

Berdasarkan hasil pencarian literatur di dapatkan tahapan evaluasi secara umum sebagai berikut:

1. Mengidentifikasi kriteria dan standar evaluasi

2. Mengumpulkan data untuk menentukan kriteria dan standar yang telah terpenuhi

3. Menginterpretasi dan meringkas data

4. Mendokumentasikan temuan dan setiap pertimbangan klinis

5. Menghentikan, meneruskan, atau merevisi rencana perawatan.

Dalam hal melakukan evaluasi keperawatan terdapat 2 macam yang perlu diperhatikan yang terdiri dari:

- Evaluasi formatif merupakan evaluasi yang berfokus pada aktivitas proses keperawatan dan hasil tindakan keperawatan. evaluasi formatif ini dilakukan segera setelah perawat mengimplementasikan rencana keperawatan yang berguna untuk menilai keefektifan tindakan keperawatan yang telah dilaksanakan. Perumusan evaluasi formatif ini meliputi 4 komponen yang dikenal dengan istilah SOAP yaitu subjektif (data berupa keluhan klien), objektif (data hasil pemeriksaan), analisis data (perbandingan data dengan teori), dan perencanaan.

- Evaluasi sumatif merupakan evaluasi yang dilakukan setelah semua aktivitas proses keperawatan telah dilakukan. evaluasi sumatif ini bertujuan untuk memonitoring dan menilai kualitas asuhan keperawatan yang telah diberikan dengan metode yang dilakukan adalah wawancara pada akhir layanan dan menanyakan respon pasien/klien dan keluarga yang terkait pada layanan keperawatan.

Pada evaluasi yang dilakukan dapat dilihat hasil evaluasi yang terkait dengan pencapaian tujuan keperawatan sebagai berikut: 1) Tujuan tercapai jika pasien/klien menunjukkan perubahan sesuai dengan standar yang telah ditentukan, 2) Tujuan tercapai sebagian atau pasien/klien masih dalam proses pencapaian tujuan jiak pasien/klien menunjukkan perubahan pada sebagian kriteria yang telah ditetapkan, 3) Tujuan tidak tercapai jika pasien/klien hanya menunjukkan sedikit perubahan dan 
tidak ada kemajuan sama sekali serta dapat timbul masalah baru.

\section{PEMBAHASAN}

Evaluasi keperawatan merupakan mengkaji respon pasien setelah dilakukan intervensi keperawatan dan mengkaji ulang asuhan keperawatan yang telah diberikan (Deswani, 2009).

Menurut Wilkinson (2007), secara umum evalusi diartikan sebagai proses yang disengaja dan sistematis dimana penilaian dibuat mengenai kualitas, nilai atau kelayakan dengan membandingkan pada kriteria yang diidentifikasi atau standar sebelumnya.

Evaluasi keperawatan ini, hal yang dilakukan secara terus menerus dalam menentukan rencana keperawatan yang efektif dan rencana keperawatan yang dilanjutkan serta merevisi atau menghentikan rencana keperawatan (Manurung, 2011).

Tahapan evaluasi keperawatan dilakukan secara periodik, sistematis, dan terencana.

Pada tahap evaluasi keperawatan ini terdapat penilaian keberhasilan asuhan keperawatan yang telah terlaksana dan tidak terlaksana. Pada asuhan keperawatan yang telah terlaksana memberikan dampak kesembuhan secara meningkat sedangkan asuhan keperawatan yang tidak telaksana memberikan dampak yang disebabkan oleh tujuan tidak realistis, tindakan keperawatan yang tidak tepat dan terdapat faktor lingkungan yang tidak diatasi.

Meskipun evaluasi keperawatan adalah langkah akhir dari proses keperawatan maka evaluasi bukan berarti akhir dari proses karena informasi yang digunakan untuk memulai siklus yang baru. Setelah mengimplementasikan asuhan keperawatan, seorang perawat perlu membandingkan respon pasien terhadap outcome yang telah direncanakan dan menggunakan informasi tersebut untuk mereview asuhan keperawatan.

\section{PENUTUP}

Pada evaluasi asuhan keperawatan secara umum diketahui bahwa hal ini menentukan perkembangan kondisi dari pasien/klien. Dalam evaluasi asuhan keperawatan ini adalah salah satu tahapan yang sangat penting dan berpengaruh pada hasil dari proses keperawatan.

Tahapan evaluasi ini memiliki peran penting dalam menjamin asuhan keperawatan secara optimal dan 
meningkatkan mutu asuhan keperawatan.

Evaluasi keperawatan ini tetap dilakukan secara terus menerus untuk melihat pencapaian asuhan keperawatan yang telah diberikan. Sehingga dalam tahap evaluasi keperawatan ini dapat memberikan perkembangan kemajuan dalam pemberian layanan kesehatan.

\section{REFERENSI}

Adawiyah, R., Thamrin, Djafar, L.

(2012). Evaluasi Pelayanan Yang Diberikan Oleh Perawat Pada Ruang Kelas III Rumah Sakit Umum Daerah Dokter Soedarso, Jurnal PMIS, 2-9.

Anggraini, Dewi, Hakim, L., Imam, C.

W. (2014). Evaluasi

Pelaksanaan Sistem Identifikasi

Pasien di Instalansi Rawat Inap

Rumah Sakit, Jurnal KB, Vol. 28, No. 1, 99-105.

Hidayat, A. Aziz Alimul. (2006).

Pengantar Kebutuhan Dasar Manusia : Aplikasi Konsep Dan

Proses Keperawatan. Jakarta: Salemba Medika.

Hidayat, A. Aziz Alimul. (2009).

Kebutuhan Dasar Manusia. Jakarta: Salemba Medika.
Kusmiyati, Yuni. (2010). Keterampilan

Dasar Praktik Klinik Keperawatan. Yogyakarta: Fitramaya.

Murwani, Arita. (2009). Keterampilan Dasar Praktek Klinik Keperawatan. Yogyakarta: Fitramaya.

Nurjannah, I. (2010). Proses Keperawatan. Yogyakarta: MocoMedia.

Nursalam. (2009). Proses dan Dokumentasi Keperawatan: Konsep dan Praktik. Jakarta: Salemba Medika.

Nursalam. (2012). Manajemen Keperawatan Aplikasi dalam Praktik Keperawatan Profesional, Edisi 3. Jakarta: Salemba Medika.

Potter \& Perry. (2005). Buku Ajar Fundamental Keperawatan, Konsep, Proses, dan Praktik, Volume 2, Edisi IV. Jakarta: EGC.

Potter \& Perry. (2009). Fundamental Keperawatan, Edisi 7. Jakarta: Salemba Medika.

Rahmat, I., Kurnia, A., Sedyowinarso, M. (2012). Evaluasi 
Pelaksanaan Sistem Pemberian Asuhan Keperawatan di Ruang Rawat Inap Terhadap Kinerja Perawat, Jurnal KM, Vol. 28, No. 1, 2-6.

Rosdahl, caroline B., dan Mary T. Kowalski. (2014). Buku Ajar Keperawatan Dasar. Edisi 10. Jakarta: EGC.

Setiawati, S., Agus Citra D. (2008). Penuntun Praktis Asuhan Keperawatan Keluarga. Jakarta: Trans Info Media.

Simamora, R. H. (2008). Peran Manajer Dalam Pembinaan Etika Perawat Pelaksana Dalam Peningkatan Kualitas Pelayanan Asuhan Keperawatan. Jurnal IKESMA.

Simamora, R. H. (2009). Dokumentasi Proses Keperawatan. Jember University Press.

Simamora, R. H. (2010). Komunikasi Dalam Keperawatan. Jember University Press. 